AKRUAL 4 (1) (2012): 1-18 $e$-ISSN: 2502-6380

\title{
AKRUAL
}

Jurnal Akuntansi

http://fe.unesa.ac.id/ojs/index.php/akrl

\section{PENERAPAN SISTEM INFORMASI AKUNTANSI BERBASIS KOMPUTER DALAM PENGAMBILAN KEPUTUSAN GUNA MENINGKATKAN EFEKTIFITAS PENDAPATAN PADA LEMBAGA PENYIARAN PUBLIK RADIO REPUBLIK INDONESIA (LPP RRI) STASIUN SUMENEP}

\author{
Alwiyah \\ Achmad Baihaki \\ Universitas Wiraraja, Sumenep \\ e-mail: alwiyahmahdaly@yahoo.com
}

Artikel diterima: 20 Mei 2012

Terakhir direvisi: 30 Juni 2012

\begin{abstract}
The Target of this research is to know the application of computerized accounting information system for decision-making and to improve the effectiveness of Lembaga Penyiaran Publik Radio Republik Indonesia (LPP RRI) Stasiun Sumenep. By using the computer application system will be carried out in several stages of decisionmaking, the stages are: recognize and define the problem, identify any alternative as a viable solution, identify the costs and benefits associated with each alternative is feasible, calculate total relevant costs and benefits of each alternative, assessing the qualitative factors, establishing an alternative that offers the greatest benefit. After an analysis of the effectiveness of revenue in the period 2008 and 2009 by using the profit centre method, we conclude that using a computerized system on LPP RRI Stasiun Sumenep calculation of the effectiveness of income more effectively in 2009 than in 2008, which at the time was still using manual systems. It also results in an increase in revenue in 2009 amounted to 2.57\%, thus the application of the system of computer-based application that provides a very good impact on revenue in the LPP RRI Stasiun Sumenep.
\end{abstract}

Keyword: Accounting Information System, decision making, earnings efectivity.

\section{PENDAHULUAN}

Tugas utama penyiaran publik adalah memberikan sejumlah informasi yang dibutuhkan oleh para pendengar agar dapat menambah wawasan dan pengetahuan serta dapat menghibur khalayak yang mendengarkannya. Didalam memberikan jasa pelayanan tersebut, penyiaran publik memperoleh penghasilan dari pendapatan jasa dan produksi yang di berikan. Salah satunya adalah iklan, dimana pendapatan dari jasa tersebut didapat dari tarif yang harus dibayar oleh mereka yang ingin memasarkan produksinya. Penentuan tarif jasa iklan tersebut merupakan suatu 
keputusan yang sangat penting. Karena keputusan tersebut dapat mempengaruhi profitabilitas suatu penyiaran publik. Sehingga perusahaan jasa ini harus memperbaiki sistem informasi yang lebih baik. Untuk mendapatkan respon yang positif dari para pendengar yang menjadi pemakai jasa disini. Dengan adanya kepercayaan dari mayarakat akan jasa yang diberikan oleh penyiaran publik ini, maka mereka para pengguna jasa akan berfikir untuk selalu memakai jasa yang dihasilkan oleh perusahaan jasa tersebut.

Oleh karenanya di Lembaga Penyiaran Publik Radio Republik Indonesia (LPP RRI) Stasiun Sumenep menerapkan sebuah sistem yaitu sistem informasi akuntansi berbasis komputer, maka dengan pemakaian sistem tersebut terutama didalam perusahaan jasa ini sangat relevan untuk menjadi sebuah sistem yang sangat sesuai dengan kebutuhan untuk lebih meningkatkan taraf modernisasi dalam pengambilan keputusan guna meningkatkan efisiensi pendapatan yang semaksimal mungkin dari produksinya ini. Dengan adanya sistem ini pula, Lembaga Penyiaran Publik Radio Republik Indonesia (LPP RRI) Stasiun Sumenep lebih mudah mengakses atau menghasilkan produksi yang lebih baik.

Maka dengan menggunakan sistem informasi akuntansi yang berbasis komputer ini dapat menumbuh kembangkan lagi sebuah ide-ide baru yang lebih inovatif dalam memberikan keputusan guna meningkatkan pendapatan didalam lembaga tersebut. Sistem informasi Akuntansi berbasiskan komputer ini juga berperan sebagai pengaman harta kekayaan perusahaan. Dengan adanya unsur-unsur pengendalian atau pengecekan dalam sistem akuntansi sehingga kecurangankecurangan dapat di hindarkan. Dalam pengolahan data pendapatan yang berbasiskan komputer memiliki program, program tersebut juga menghasilkan bentuk tampilan data elektronik sehingga dengan sistem informasi berbasiskan komputer ini dapat memberikan perbedaan antara kuantitas yang diserahkan pada order penjualan yang bisa timbul apabila terjadi antara kuantitas fisik barang dengan kuantitas yang termuat pada master file. Meskipun demikian, tidak berarti bahwa para petugas itu seluruhnya dikeluarkan dari perusahaan.

Ada beberapa petugas yang harus dipertahankan untuk tugas-tugas tertentu yang tidak dapat digantikan mesin. Jika suatu organisasi semakin berkembang dan terdesentralisasi, CPU terpusat dengan terminal-terminal maka akan menjadi kurang efektif, karena kebutuhan informasi oleh manajemen tingkat lokal tidak dapat ditanggapai dengan cepat. Secara periodik sistem lokal harus mentransmisikan ikhtisar data ke CPU pusat untuk digabungkan kedalam laporan gabungan pusat atau untuk manajemen kas terpusat. Dengan demikian karakteristik utama dari sistem pengolahan data dengan metode distribusi ini adalah bahwa dengan sistem informasi berbasis komputer tersebut kebutuhan informasi manajemen pusat diperoleh dari data lokal, namun dengan tetap memberi kebebasan kepada sistem lokal untuk melakukan pengolahan data sendiri. 
Dengan demikian dapat diambil rumusan masalah: "Bagaimanakah peran sistem informasi akuntansi berbasis komputer dalam pengambilan keputusan guna meningkatkan efektifitas pendapatan pada Lembaga Penyiaran Publik Radio Republik Indonesia (LPP RRI) Stasiun Sumenep? ”

\section{KAJIAN PUSTAKA}

\section{Pengertian Sistem informasi Akuntansi}

Pengertian sistem informasi akuntansi menurut Nugroho (2001:4) adalah "Susunan berbagai formulir catatan, peralatan, termasuk komputer dan perlengkapannya serta alat komunikasi, tenaga pelaksananya, dan laporan terkoordinasikan secara erat yang didesain untuk mentransformasikan data keuangan menjadi informasi yang dibutuhkan manajemen". Apabila dikaitkan dengan pengertiannya sebagai suatu sistem informasi akuntansi akan nampak seperti gambar berikut ini:

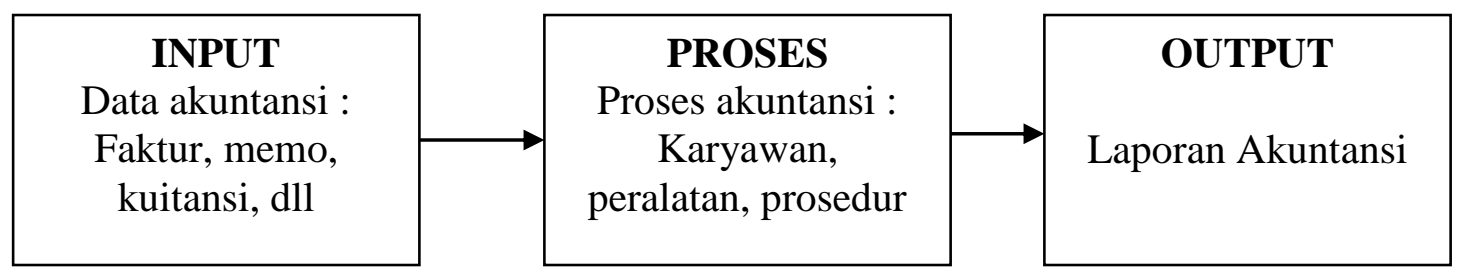

\section{Gambar 1. Rangkaian unsur dalam sistem informasi akuntansi}

\section{a. Penugasan sistem informasi akuntansi}

Seorang akuntan pada umumnya adalah seorang yang ahli dalam menyusun sistem. Ia harus dapat menyusun sistem informasi akuntansi sesuai dengan yang ditugaskan perusahaan. Pada umumnya terdapat tiga jenis penugasan sistem informasi akuntansi menurut Nugroho (2001: 5) yaitu :

1). Mendesain sistem informasi akuntansi yang baru.

2). Memperluas sistem akuntansi yang ada untuk memenuhi perluasan usaha.

3). Penyesuaian beberapa tahap atau bagian dari sistem dan prosedur yang ada.

b. Peranan sistem informasi akuntansi dalam organisasi perusahaan

Pemakaian informasi akuntansi dapat dibagi kedalam dua kelompok :

a. Kelompok internal meliputi :

1) Para manajer yang terdapat pada perusahaan itu sendiri yang kebutuhannya sangat tergantung pada jenjang organisasi atau pada fungsi tertentu yang dilaksanakannya.

2) Pada jenjang yang lebih tinggi akan lebih banyak waktu yang dibutuhkan utuk perencanaan, misalnya menetapkan strategi penjualan, perumusan rencana pembukaan cabang baru, dan sebagainya.

3) Terlihat pula bahwa manajer yang berada di jenjang yang lebih bawah cenderung memerlukan informasi yang bersifat rutin dan terinci. 


\section{b. Kelompok Eksternal}

Pada umumya kelompok eksternal memerlukan informasi yang bersifat umum dalam bentuk laporan keuangan yang terdiri dari neraca, perhitungan laba-rugi, laporan arus kas.

\section{Sistem informasi yang berbasiskan komputer}

Menurut James (2002:364) dalam sebuah lingkungan sistem informasi berbasis komputer, transaksi seringkali diotorisasi oleh peraturan-peraturan yang sudah terprogram dalam program-program komputer. Dalam kasus otorisasi gejalagejala adanya masalah yang nantinya dapat memberikan suatu perusahaan mengalami kerugian yang substansial. Dengan adanya masalah-masalah tersebut maka dituntutlah tanggung jawab untuk mewujudkan otorisasi transaksi yang tepat terletak langsung pada ketepatan dan integritas program-program komputer yang melakukan tugas ini. Teknik-teknik control yana memberikan akurasi dan integritas control akan diperdalam kemudian akan disebutkan beberapa teknik diantaranya adalah:

a. Pemisahan Tugas

Dalam sebuah sistem manual, salah satu aktivitas yang penting adalah pemisahan tugas-tugas yang bertentangan selama pemprosesan transaksi. Para individu diberikan tanggung jawab untuk melakukan aspek-aspek terbatas dari transaksi untuk mewujudkan tiga tujuan kontrol. Adapun ketiga tujuan tersebut adalah :

1) Otoritas transaksi terpisah dari pemprosesan transaksi.

2) Pengawasan aktiva terpisah dari tanggung jawab pembukuan aktiva.

3) Organisasi harus distrukturisasi sehingga berhasilnya suatu kecurangan memerlukan kolusi diantara dua atau lebih individual dengan tanggung jawab yang berseberangan.

b. Pengawasan

Pengawasan sering kali digunakan sebagai control pendukung dalam situasi dimana pemisahan tugas yang memadai tidak mungkin karena alasan-alasan ekonomis atau praktis.

c. Catatan Akuntansi

Dalam sebuah lingkungan manual, organisasi harus menyimpan catatan akuntansi dalam bentuk dokumen sumber, jurnal, dan buku besar. Catatan-catatan ini menjadi jejak audit untuk informasi-informasi penting yang dapat digunakan untuk menelusuri transaksi dari saat dimulai sampai pada disposisi terakhir.

Sistem Informasi Berbasis Komputer atau Computer Based Information System (CBIS) merupakan sistem pengolahan suatu data menjadi sebuah informasi yang berkualitas dan dapat dipergunakan sebagai alat bantu yang mendukung pengambilan keputusan, koordinasi dan kendali serta visualisasi dan analisis. Perangkat dan hasil kerja penyajian hasi proses komputer dapat dilihat dalam dua bentuk utama yaitu softcopy dan hardcopy. Softcopy adalah tampilan berupa gambar diam ataupun bergerak dalam monitor komputer sedangkan hardcopy berupa gambar tampilan hasil kerja komputer dalam bentuk cetakan. Bekerja dengan komputer 
sebagai perangkat pengumpul, penyimpan dan penyaji data akan dapat memberikan hasil yang maksimal jika dioperasikan dalam kondisi kerja yang baik.

Sistem Informasi Akuntansi berbasis manual merupakan organisasi file pada aplikasi-aplikasi pada umumnya tipis dan data serta logika terikat pada file-file dan program tertentu. Pada dasarnya, komputer memproses data dengan salah satu dari dua metode berikut ini:

1). Sistem Batch processing

Batch processing adalah metode pemrosesan data dengan proses updating (pemutakhiran) dilakukan secara periodik dalam jangka waktu.

2). Sistem immediate Processing (On-Line)

Sistem Immediate Processing atau on-line processing adalah sistem dimana setiap transaksi direkam dan diproses setelah terjadi.

3). Evolusi Sistem Informasi Berbasis Komputer
a). Fokus awal pada data
b). Fokus Baru pada informasi
c). Fokus revisi pada pendukung keputusan
d). Fokus potensial pada konsultasi

\section{Sistem pengolahan data pendapatan berbasis komputer}

Menurut Nugroho Widjajanto (2001:333-345) menjelaskan bahwa sistem pengolahan data pendapatan berbasis komputer menggunakan sistem batch processing yang dalam hal ini dibagi kedalam tiga bagian yaitu:

a. Pencatatan Order penjualan dan pengecekan kelayakannya

Pencatatan order penjualan dan penelitian kelayakan pesanan meliputi kegiatan untuk menanggapi pesanan pelanggan.

b. Pengiriman Barang ke lapangan dan penagihan melalui faktur

Apabila pesanan pelanggan dapat dipenuhi, maka data tersebut tersebut dicetak dalam dua jenis yaitu:

1). Dokumen kesanggupan memenuhi pesanan.

2). Order Penjualan

\section{Sistem pendukung keputusan dalam sistem informasi}

Sistem informasi akuntansi merupakan salah satu subsistem dari informasi manajemen. Informasi yang tidak bersifat keuangan dan tidak dihasilkan dari data transaksi dengan sendirinya tidak tercakup dalam pengertian sistem informasi akuntansi. Sistem informasi manajemen, dengan semua subsistemnya pada dasarnya dapat dikelompokkan kedalam tiga tujuan kelompok sesuai dengan jenjang manajemen yang memerlukan informasi. Tiga kelompok itu menurut nugroho widjajanto (2001:212) adalah :

a. Transaction Processing Sistem

Transaction processing sistem adalah suatu sistem yang didalamnya memuat laporan-laporan periodik yang dihasilkan yang didalamnya terdapat laporan distribusi penjualan, posisi kas harian. Tujuan utama transaction processing 
sistem adalah untuk memberikan gambaran tentang hasil usaha dari waktu ke waktu yang dihasilkan oleh transaction processing sistem nampak dalam bentuk laporan periodik, atau mengalir keatas menuju operational support sistem.

b. Operational Support Sistem (OSS)

Operational support sistem adalah suatu sistem pengolahan data yang bertujuan untuk membantu perencanaan dan pengendalian operasi. Sasarannya adalah untuk membantu penyelesaian tugas-tugas yang bersifat terstruktur serta permasalahan jangka pendek. Oleh sebab itu, OSS terfokus pada keputusan-keputusan untuk perencanaan taktis jangka pendek serta pengendalian operasional yang dikeluarkan oleh para manajer madya atau bawah.

c. Response Time (Rentang Waktu Tanggapan)

Kebutuhan proses operasi yang dikendalikan serta konteks dari aplikasi bersangkutan. Proses pabrikasi yang memerlukan kecermatan tinggi kemungkinan memerlukan rentang waktu tanggapan yang sangat singkat, bisa sepersekian detik, agar pengendalian dapat dilakukan dengan ketelitian maksimal. Proses fisik seperti itu pada umumnya dikendalikan oleh komputer yang di desain khusus. Sedangkan proses bisnis yang berorientasi transaksi.

\section{Penentuan Laba}

Menurut Halim dan Supomo (2007) menyebutkan bahwa Pusat laba umumnya terdapat pada organisasi yang dibagi-bagi berdasarkan divisi-divisi penghasil laba, biaya pada pusat pertanggung jawaban yang dipimpinnya dengan demikian, pusat laba merupakan pusat pertanggung jawaban yang masukan dan keluarannya diukur dengan menghitung selisih antara pendapatan dengan biaya. Dengan rumus sebagai berikut

$$
\text { Pusat Laba }=\sum \text { Pendapatan }-\sum \text { Biaya }
$$

\section{METODE PENELITIAN}

\section{Teknik Pengumpulan Data}

1. Interview

2. Dokumentasi, artinya mengadakan pengumpulan data-data dengan mencatat dari dokumen-dokumen yang ada di Lembaga Penyiaran Publik Radio Republik Indonesia (LPP RRI) Stasiun Sumenep, seperti: Surat kontrak pembuatan iklan, laporan keuangan selama dua tahun terakhir periode 2008-2009, formulir pembayaran, laporan gaji pegawai, bagan organisasi yang ada di lembaga tersebut, formulir pendapatan dari pembuatan iklan, surat persetujuan atas biaya yang akan dikeluarkan. Setelah itu dengan dokumen atau data tersebut akan dilakukan sebuah analisa apakah sistem yang digunakan melalui sistem komputer itu akan benar dapat memberikan dampak positif serta dapat memberikan pendapatan yang semaksimal mungkin dengan biaya yang seminimal mungkin.

3. Studi Kepustakaan 


\section{Teknik Pengolahan Data}

Peneliti menganalisis data dengan cara editing yaitu; proses perolehan data mentah yang telah didapat dari perusahaan yang kemudian data-data tersebut di resume sesuai dengan permasalahan yang diteliti. Peneliti juga merangkum seluruh jawaban dari responden berdasarkan kelompoknya dan kemudian data tersebut dianalisis.

\section{Teknik Analisa Data}

1. Teknik Pengambilan Keputusan

Dalam suatu pengambilan keputusan maka digunakan langkah-langkah sebagai berikut :

a. Kenali dan tetapkan masalah

b. Identifikasi setiap alternative sebagai solusi yang layak atas masalah tersebut; eliminasi alternative yang secara nyata tidak layak.

c. Identifikasi biaya dan manfaat yang berkaitan dengan setiap alternative yang layak. Klasifikasilah biaya dan manfaaat sebagai relevan atau tidak relevan serta eliminasilah biaya dan manfaat yang tidak relevan dari pertimbangan.

d. Hitunglah total biaya dan manfaat relevan masing-masing alternatif

e. Nilai faktor-faktor kualitatif

f. Tetapkan alternative yang menawarkan manfaat terbesar.

2. Kualitatif

Dalam metode pengumpulan data ini penulis harus menganalisis terlebih dahulu, yaitu dengan menggunakan metode kualitatif. Metode kualitatif disini maksudnya adalah mendeskripsikan serta menganalisis data yang telah didapat dari lapangan penelitian sehingga dapat mengetahui tingkat efektif atau tidaknya sistem informasi akuntansi berbasis komputer ini didalam pengambilan keputusan yang nantinya juga akan berpengaruh terhadap efektifitas pendapatan yang diterima di Lembaga Penyiaran Publik Radio Republik Indonesia (LPP RRI) Stasiun Sumenep.

Adapun data yang akan dianalisis dan dideskripsikan yaitu :

a. Analisa bagan alir atas penerapan sistem informasi akuntansi berbasis komputer dalam mendukung kecepatan pengambilan keputusan guna meningkatkan efektifitas pendapatan.

b. Memberikan penilaian atas kelebihan dan kelemahan dari sistem informasi akuntansi berbasis komputer guna meningkatkan efektifitas pendapatan.

\section{Kuantitatif}

Kuatitatif adalah data yang bersumber dari obyek penelitian dimana data berupa angka-angka dan informasi yang berkaitan dengan masalah penelitian yang dikumpulkan, diklasifikasikan dan dianalisa berdasarkan teori-teori yang ada.

Data kuantitatif meliputi data jumlah karyawan bagian produksi, jumlah anggaran operasional, jumlah sarana dan prasarana proses produksi seperti alat pembuatan iklan, berita, dan sport, serta lamanya proses pelaksanaan produksi. 


\section{PEMBAHASAN}

Tabel 1. Kelemahan Dan Kelebihan Sistem Manajemen Aplikasi Keuangan LPP RRI Stasiun Sumenep

\begin{tabular}{|c|c|}
\hline Sistem Manual & Aplikasi Komputer \\
\hline Kelebihan & Kelebihan \\
\hline $\begin{array}{l}\text { 1. Dengan dipindahnya tenaga } \\
\text { manusia yang diorientasikan pada } \\
\text { kegiatan proses produksi diamana }\end{array}$ & $\begin{array}{l}\text { 1. Data dapat langsung dimasukkan dan ditarik } \\
\text { setiap saat.sehingga master file akan selalu - } \\
\text { mutakhir (up-to-date) }\end{array}$ \\
\hline $\begin{array}{l}\text { akan dapat menambah tingkat } \\
\text { pendapatan di LPP RRI Stasiun } \\
\text { Sumenep. }\end{array}$ & $\begin{array}{l}\text { 2. Pesanan klien dapat diterima lebih cepat, } \\
\text { dan kesanggupan memenuhi pesanan akan } \\
\text { dapat dikirimkan dengan cepat pula. }\end{array}$ \\
\hline $\begin{array}{l}\text { 2. Klien dapat bernegosiasi } \\
\text { langsung dengan kepala jabatan. }\end{array}$ & $\begin{array}{l}\text { 3. Pesanan pelanggan dapat diterima lebih } \\
\text { cepat dan lebih akurat sehingga bebas }\end{array}$ \\
\hline $\begin{array}{l}\text { 3. Peralatan dapat digunakan oleh } \\
\text { siapa saja yang berkepentinga. }\end{array}$ & $\begin{array}{l}\text { kesalahan karena setiap kesalahan akan } \\
\text { langsung dapat diketahui karena } \\
\text { menggunakan format yang sudah baku di }\end{array}$ \\
\hline Kelemahan & layar monitor. \\
\hline $\begin{array}{l}\text { 1. Didalam penyelesaian produksi } \\
\text { lebih membutuhkan waktu yang } \\
\text { sangat lama. }\end{array}$ & $\begin{array}{l}\text { 4. Pihak SDM akan menempatkan tenaga } \\
\text { manusia yang sesuai dengan kemampuannya. } \\
\text { Kelemahan }\end{array}$ \\
\hline $\begin{array}{l}\text { 2. Peralatan yang digunakan kurang } \\
\text { maksimal untuk mendapatkan } \\
\text { hasil produksi yang bagus. }\end{array}$ & $\begin{array}{l}\text { 1. Akan banyak tenaga manusia yang akan } \\
\text { diorientasikan pada kegiatan lain sehingga } \\
\text { mendapatkan pendapatan yang lebih efektif. }\end{array}$ \\
\hline $\begin{array}{l}\text { 3. Tahap pengambilan keputusan } \\
\text { juga tidak dapat maksimal untuk } \\
\text { segera memproses produksi. }\end{array}$ & 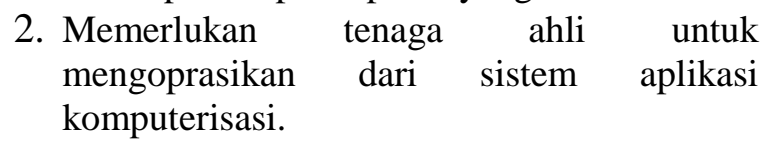 \\
\hline 4. Meningkatnya biaya-biaya yang & 3. Akan bertambahnya biaya operasional \\
\hline $\begin{array}{l}\text { timbul didalam proses produksi } \\
\text { sehingga dapat mempengaruhi } \\
\text { terhadap pendapatan. }\end{array}$ & $\begin{array}{l}\text { 4. Jika ada pasword terus lupa dengan pasword } \\
\text { maka program tersebut tidak dapat } \\
\text { digunakan lagi. }\end{array}$ \\
\hline
\end{tabular}

Sumber data : LPP RRI Stasiun Sumenep

a. Pemakaian sistem manual

Dengan pemakaian sistem manual di LPP RRI (Lembaga Penyiaran Publik Radio Republik Indonesia). Stasiun Sumenep ini memberikan dampak yang sangat kurang efektif didalam pengambilan suatu keputusan. Dengan sistem manual sistem pengerjaannya menjadi sangat lambat dan harus menempuh berjam-jam bahkan berbulan-bulan didalam menyelesaikan suatu produksi di bidang jasa ini. Penggunaan sistem manual akan menambah biaya operasional yang sangat tinggi. Sehingga didalam pengambilan keputusannyapun akan lama. Karena dengan pemprosesan produksi yang lama sehingga apabila harus memutuskan suatu keputusannyapun akan semakin sulit dan perlu waktu yang cukup lama. 
Proses produksi iklan disini sangat membutuhkan waktu yang lama, dikarenakan didalamnya masih ada tahap pemasaran dari bagian layanan usaha kepada klien setelah itu antara klien dengan RRI mengadakan kesepakatan atas harga dari iklan yang akan diproduksinya. Apabila sudah ada kesapakatan antara kedua belah pihak maka dapat diproses untuk produksi iklan dimana pemrosesannya masih sangat lama karena masih ada pembuatan naskah, penentuan artis dan narator apabila sudah terdapat keduanya maka diproseslah tahap rekaman yang disini masih menggunakan kaset dan direkam melalui tape recorder, apabila sudah mendapatkan suara dari artis dan narator tersebut maka tahap selanjutnya adalah tahap editing dimana tahap ini adalah penggabungan suara dan lagu melalui tape sehingga menjadi bahan yang siap di sajikan, apabila sudah selesai tahap proses produksi ini maka dikirimkanlah master produksi atau hasil produksi kepada klien untuk mendapatkan persetujuan dari klien apakah iklan yang diinginkannya itu sudah sesuai atau tidak apabila sudah sesuai akan dibuatkan kontrak kerja antara pihak RRI dengan klien, dengan demikian transaksi keuanganpun dapat terjadi dengan persetujuan dan keputusan dari kepala stasiun maka disiarkanlah iklan yang telah diproduksi tersebut. Tetapi apabila master file tidak sesuai dengan apa yang diharapkan maka proses selanjutnya akan diproses ulang sampai ada persetujuan dari pihak klien.

Seperti juga pada proses keuangan yang digunakan secara sistem manual. Proses pelaporannya sangat rumit dimana didalam proses pelaporannya sangat membutuhkan waktu dan juga sangat memerlukan biaya yang sangat cukup besar. Dengan pembebanan biaya yang sangat besar maka hasil pendapatan juga akan berkurang. Proses pembuatan laporan keuangan ini masih harus melalui pencatatan tangan kepada buku yang sudah tersedia. Formulir atau bukti transaksi dimasukkan pada pembukuan dengan cara ditulis tangan dan proses pelaporan kepada pusat dengan menggunakan laporan pembukuan yang di kirim melalui KPPN yang ditunjuk oleh pusat. Sehingga apabila mau melaporkan atas keuangan tersebut masih harus ke pamekasan untuk mengirimkan laporannya tersebut.

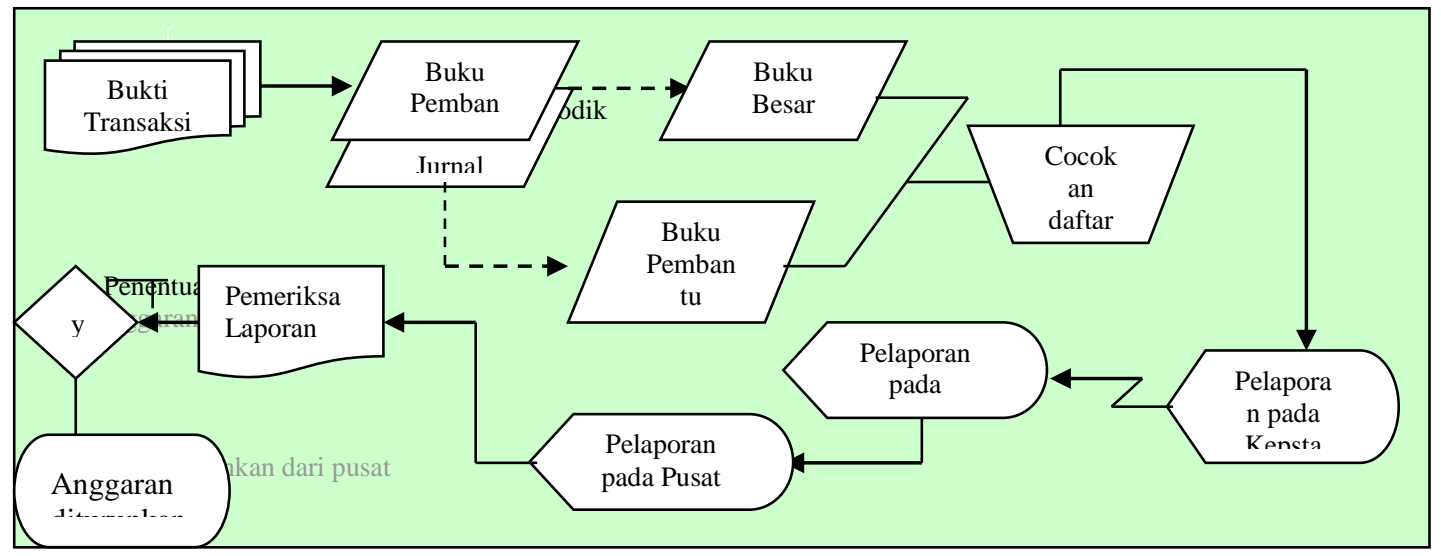

Sumber Data : LPP RRI Stasiun Sumenep dan dioleh Oleh Peneliti

Gambar 3. Prosedur Pelaporan Keuangan LPP RRI Stasiun Sumenep 
b. Penerapan sistem aplikasi komputer

Seiring berkembangnya zaman maka perkembangan sistemnya juga semakin sangat modern. Apalagi dengan gedung yang representatif dan lokasi serta alat komunikasi yang sudah sangat canggih maka saat ini dapat diterapkan pula sistem komputerisasi dari masing-masing bagian. Dengan sistem aplikasi ini maka terhadap pembebanan biaya pun dapat di kondisikan seminimal mungkin. Aplikasi yang dipakai oleh RRI adalah SIMAK (Sistem Manajemen Aplikasi Keuangan) dimana aplikasi ini merupakan aplikasi yang online dari kantor pusat.

Sistem aplikasi komputer ini apabila digunakan maka semua data yang dimasukkan akan terkirim secara otomatis kepada masing-masing bagian yang ada di RRI dan dapat mengirimkan data secara langsung melalui e-mail, fax, dan berupa CD kepada RRI pusat guna melaporkan data keuangan dan data sebagainya. Seperti halnya juga pembuatan iklan dengan menggunakan sistem aplikasi komputer yang sering disebut sistem aplikasi Cool Edit.

Sistem aplikasi ini merupakan sistem aplikasi yang sangat efektif didalam pembuatan iklan. Proses dalam melakukan pembuatan iklan sangatlah mudah dan cepat karena disini sudah menggunakan sistem online.

Dengan menggunakan sistem aplikasi komputer ini maka pengerjaannyapun semakin cepat. Yang biasanya membutuhkan proses yang lama maka dengan sistem aplikasi komputer dapat mengefisienkan waktu maupun biaya yang dipakai. Dengan sistem ini klien hanya dapat memberikan persetujuan melalui komputer. Karena sistem ini sudah dilengkapi dengan sistem aplikasi manajemen. Jadi dari pemasaran layanan usaha lewat media internet yang online, mereka memasarkan tentang program apa saja yang ada di LPP RRI Stasiun Sumenep jadi yang biasanya dengan sistem manual mereka apabila ada klien yang mau memasarkan iklannya dengan datang terlebih dahulu ke RRI maka dengan sistem komputerisasi klien hanya melihat program apa saja yang ada di RRI sehingga juga dapat memberikan efisiensi kepada klien atas kinerjanya. Dengan menggunakan sistem komputer ini, maka klien dapat melihat berapakah biaya yang harus dikeluarkan untuk suatu pembuatan iklan yang ingin dipasarkannya. Karena apabila sudah terjadi kesepakatan antara kedua belah pihak maka dikirimkanlah harga yang harus dibayar atas pembuatan iklan tersebut. Apabila sudah sepakat tentang biaya tersebut maka pihak RRI langsung memproses pembuatan iklan yang disini memakai sistem Cool Edit dimana sistem ini dapat memproduksi suatu iklan hanya dalam hitungan menit.

Berbeda dengan sistem manual, sistem manual proses pembuatannya masih menggunakan Tape Recorder dan Kaset untuk menyatukan suara dan musik. Di sistem aplikasi coll edit ini mengedit antara suara dan musik langsung menjadi satu kesatuan dalam komputer sehingga pembuatan dan pengeditannya sangat mudah dan cepat. Apabila sudah selesai proses pembuatan iklan maka di kirimkan hasil iklan tersebut kepada pihak klien melalui e-mail, atau berupa CD maka apabila sudah setuju tentang iklan tersebut maka dibuatlah kontrak kerja antara pihak RRI dan Klien dimana pembayarannya langsung dimasukkan pada rekening 
bank. Apabila sudah terjadi transaksi maka bagian layanan usaha memberikan laporan kepada kepala stasiun yang selanjutnya untuk disiarkan melalui radio.

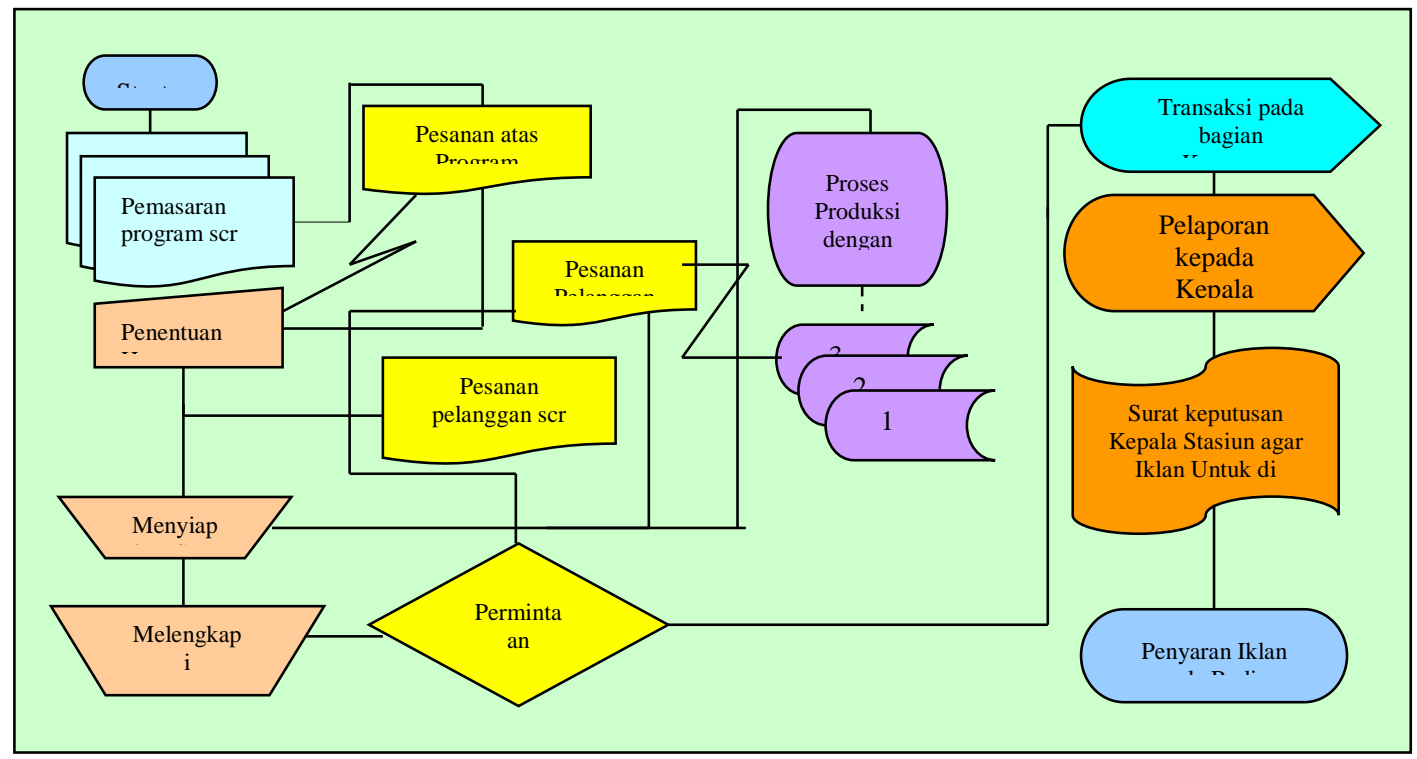

Sumber Data : LPP RRI Stasiun Sumenep dan dioleh Oleh Peneliti

\section{Gambar 4. Prosedur Pembuatan Iklan Penggunaan sistem aplikasi Coll Edit LPP RRI Stasiun Sumenep}

Sama halnya dengan proses pelaporan keuangan yang sekarang ini memakai SIMAK (Sistem Manajemen Aplikasi Komputer) dengan adanya sistem ini pelaporan keuangan yang dilakukan berbeda dengan pelaporan keuangan secara manual. Pelaporan keuangan disini langsung memproses menggunakan sistem aplikasi dimana sistem aplikasi ini merupakan sistem yang diapakai oleh RRI yang sistemnya sudah di tentukan oleh pusat. Pelaporan keuangan langsung dilaporkan melalui alamat e-mail dengan menggunakan sistem aplikasi ini RRI dapat mengefektifkan biaya yang harus dikeluarkan sehingga setiap kepala bagian dapat secepatnya mengambil suatu keputusan didalam menentukan tingakatan pendapatan dan biaya yang harus dikeluarkan. Biaya yang relevan akan dapat menambah pendapatan yang semaksimal mungkin, dengan adanya sistem aplikasi kompueterisasi ini maka sistem kinerjapun berubah. Sistem kinerja yang biasanya didalam pembuatan laporan dikerjakan berbulan bulan maka dengan sistem aplikasi dapat terselesaikan dengan cepat.

Dengan menggunakan Sistem Manajemen Aplikasi Keuangan pelaporan terhadap pusat menjadi sangat mudah dan cepat sehingga apabila harus mengambil suatu keputusan didalam penetapan anggaran dapat dilakukan dengan cepat karena sistemnya sudah tidak menggunakan sistem manual yang pelaporannya masih melalui beberapa tahapan. Tetapi dengan menggunakan sistem aplikasi seperti ini pengiriman laporan keuangannya langsung dikirimkan melalui e-mail. Dan sistem 
ini juga tidak bisa sembarangan orang yang dapat mengerjakannya, karena sistem ini sudah di buat dan personal yang mampu dalam sistem ini harus melalui pelatihan terlebih dahulu guna mendapatkan pelatihan didalam penyusunan laporan keuangan. Serta dengan menggunakan Sistem Manajemen Aplikasi Keuangan ini pelaporannya tidak dapat dibuat atau dipalsukan karena ini merupakan sebuah sistem yang berkaitan dengan bagian-bagian lainnya. Disini penggunaan aplikasi sangat menentukan kecepatan pengambilan suatu keputusan terhadap suatu masalah yang terjadi. Seperti gambar berikut ini:

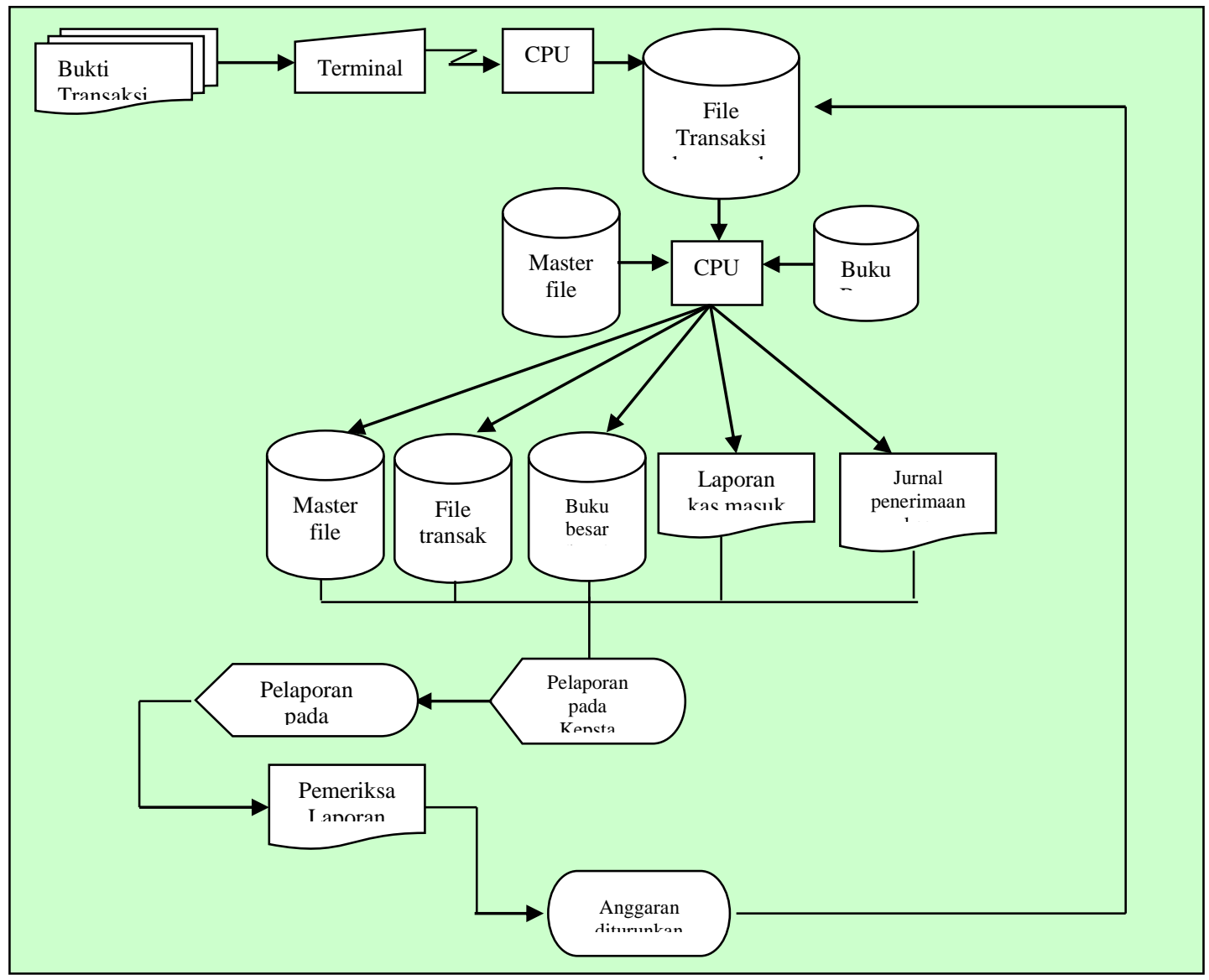

Sumber Data : LPP RRI Stasiun Sumenep dan dioleh Oleh Peneliti

\section{Gambar 5. Prosedur Penyusunan Laporan Keuangan}

Berikut ini adalah beberapa informasi keuangan LPP RRI Stasiun Sumenep yang diperoleh penulis yaitu: 
Tabel 2. Pendapatan LPP RRI Stasiun Sumenep Periode 2008 dan 2009

\begin{tabular}{lll}
\hline Bulan & Periode 2008 & Periode 2009 \\
\hline Januari & Rp. 54.252 .970 & Rp. 33.073.250 \\
\hline Pebruari & Rp. 47.123 .850 & Rp. 45.610.950 \\
\hline Maret & Rp. 31.788 .100 & Rp. 55.684.950 \\
\hline April & Rp. 36.766 .450 & Rp. 73.202 .450 \\
\hline Mei & Rp. 32.474 .810 & Rp. 80.786 .700 \\
\hline Juni & Rp. 19.369 .450 & Rp. 39.550.200 \\
\hline Juli & Rp. 20.069 .200 & Rp. 26.096.975 \\
\hline Agustus & Rp. 41.270 .950 & Rp. 34.501.720 \\
\hline September & Rp. 30.490.600 & Rp. 24.389.550 \\
\hline Oktober & Rp. 38.024.200 & Rp. 17.767 .000 \\
\hline Nopember & Rp. 16.762 .000 & Rp. 19.425 .000 \\
\hline Desember & Rp. 29.818.350 & Rp. 12.705 .000 \\
\hline Jumlah & Rp. 398.210.930 & Rp. 462.793.745
\end{tabular}

Sumber: LPP RRI Stasiun Sumenep data diolah peneliti

Dari data diatas maka dapat dilihat bahwa perbedaan antara tahun 2008 dengan tahun 2009 berbeda. Pada tahun 2008 ini penggunaan sistemnya berbasis manual sehingga pendapatan disini juga dapat mempengaruhi terhadap tingkatan pendapatan. Pada tahun 2009 disini sudah menerapkan sistem aplikasi komputer sehingga dengan pemakaian sistem aplikasi yang berbasis komputer ini dapat meningkatkan pendapatan sebesar $1 \%$. Untuk mendapatkan efektifitas pendapatan maka perlu dihitung juga biaya-biaya yang mempengaruhi tingak pendapatan. Adapun biaya-biaya yang mempengaruhi atas pendapatan tersebut adalah sebagai berikut:

Tabel 3. Perbandingan Biaya LPP RRI Stasiun Sumenep Periode 2008 dan 2009

\begin{tabular}{lll}
\hline Bulan & Periode 2008 & Periode 2009 \\
\hline Januari & Rp. 28.870 .000 & Rp. 31.050.000 \\
\hline Pebruari & Rp. 26.045.100 & Rp. 29.971.000 \\
\hline Maret & Rp. 25.572.000 & Rp. 28.327.000 \\
\hline April & Rp. 26.675 .700 & Rp. 28.186.200 \\
\hline Mei & Rp. 29.102 .000 & Rp. 30.903.400 \\
\hline Juni & Rp. 44.381.200 & Rp. 28.585.800 \\
\hline Juli & Rp. 31.360 .000 & Rp. 34.930.200 \\
\hline Agustus & Rp. 41.089 .000 & Rp. 28.397.200 \\
\hline September & Rp. 30.750.000 & Rp. 28.457.365 \\
\hline Oktober & Rp. 29.722.250 & Rp. 31.261.100 \\
\hline Nopember & Rp. 30.465 .000 & Rp. 30.396.200
\end{tabular}




\begin{tabular}{cll}
\hline Bulan & Periode 2008 & Periode 2009 \\
\hline Desember & Rp. 29.375 .000 & Rp. 32.417.000 \\
\hline Jumlah & Rp. 373.407.250 & Rp. 362.882.465 \\
\hline Sumber: LPP RRI Stasiun Sumenep dan diolah peneliti &
\end{tabular}

Berdasarkan data pembiayaan, maka dapatlah di bandingkan bahwa antara pemakaian sistem manual dengan sistem aplikasi komputer maka tingkat pembiayaannyapun akan lebih relatif rendah daripada pemakaian sistem manual hanya saja di dalam aplikasi komputer biaya gaji meningkat sebesar Rp. 27.500.000 dikarenakan adanya kenaikan gaji pegawai yang berasal dari pusat, penurunan tingkat biaya dari tahun 2008 ke tahun 2009 sebesar Rp. 10.524.785 dapat dipersentasekan sebesar $1 \%$ dari sistem manual. Sehingga apabila ingin mengetahui efektif atau tidaknya suatu pendapatan maka dapatlah diukur dengan metode penentuan pusat laba dengan rumus seperti di bawah ini:

Perhitungan efektifitas pendapatan periode 2008

Penentuan Laba $=\sum$ Pendapatan $-\sum$ Biaya

Efektifitas Pendapatan = Rp. $398.210 .930-$ Rp. 373.407 .250

$=$ Rp. 24.803 .680

Perhitungan efektifitas pendapatan periode 2009

Efektifitas Pendapatan = Rp. 426.793.745-Rp. 362.882.465

$=$ Rp. 63.911 .280

Setelah dilakukan analisis tentang efektifitas pendapatan pada periode 2008 dan 2009 dengan menggunakan metode pusat laba tersebut maka selaku peneliti kami menyimpulkan bahwa dengan menggunakan sistem komputerisasi pada LPP RRI Stasiun Sumenep maka perhitungan efektifitas pendapatan lebih efektif pada tahun 2009 dari pada tahun 2008 yang pada saat itu masih menggunakan sistem manual. Sehingga menyebabkan adanya peningkatan pendapatan di tahun 2009 sebesar Rp. 39.107 .600 yang peningkatannya setara dengan $2.57 \%$, dengan demikian penerapan sistem aplikasi yang berbasis komputer ini memberikan dampak yang sangat baik terhadap pendapatan di LPP RRI Stasiun Sumenep.

Tabel 4. Proyeksi Neraca Periode 2008 dan 2009

\begin{tabular}{lll}
\hline Nama Perkiraan & $\mathbf{2 0 0 8}$ & $\mathbf{2 0 0 9}$ \\
\hline ASET & & \\
Aset Lancar & & \\
$\quad$ Kas & Rp. 25.000 .000 & Rp. 36.500 .000 \\
Persediaan & Rp. 27.500 .000 & Rp. 42.120 .000 \\
$\quad$ Jumlah Aset Lancar & Rp.52.500.000 & Rp.78.620.000 \\
\hline
\end{tabular}




\begin{tabular}{|c|c|c|}
\hline Nama Perkiraan & 2008 & 2009 \\
\hline \multicolumn{3}{|l|}{ Aset Tetap } \\
\hline Tanah & Rp.256.455.000 & Rp. 256.455 .000 \\
\hline Peralatan & Rp.20.520.500 & Rp. 22.585 .300 \\
\hline Gedung dan Bangunan & Rp.35.325.000 & Rp. 41.212 .000 \\
\hline Inventaris Kantor & Rp.40.000.050 & Rp. 43.452 .000 \\
\hline Penyusutan & Rp. (3.250.000) & Rp. (4.673.000) \\
\hline Aset Tetap Lainnya & Rp.35.650.000 & Rp. 38.900 .000 \\
\hline Jumlah Aset tetap & Rp.384.690.550 & Rp.397.931.300 \\
\hline Jumlah Aset & Rp.437.190.550 & Rp.476.551.300 \\
\hline \multicolumn{3}{|l|}{ KEWAJIBAN } \\
\hline \multicolumn{3}{|l|}{ Kewajiban Jangka Pendek } \\
\hline Uang muka dari KPPN & Rp.250.000.000 & Rp.225.000.000 \\
\hline Jumlah Kewajiban Jangka Pendek & Rp.250.000.000 & Rp.225.000.000 \\
\hline Jumlah Kewajiban & Rp.250.000.000 & Rp.225.000.000 \\
\hline \multicolumn{3}{|l|}{ EKUITAS DANA } \\
\hline EKUITAS DANA LANCAR & Rp.173.500.000 & Rp.214.550.000 \\
\hline Cadangan Persediaan & Rp.173.500.000 & Rp.214.550.000 \\
\hline \multicolumn{3}{|l|}{ Jumlah Ekuitas Dana Lancar } \\
\hline EKUITAS DANA INVESTASI & Rp.13.690.550 & Rp. 37.001 .300 \\
\hline Diinvestasikan dalam aset tetap & Rp.13.690.550 & Rp. 37.001.300 \\
\hline Jumlah Ekuitas Dana Investasi & Rp.187.190.550 & Rp.251.551.300 \\
\hline Jumlah Ekuitas Dana & Rp.437.190.550 & Rp.476.551.300 \\
\hline Jumlah Kewajiban dan Ekuitas Dana & & \\
\hline
\end{tabular}

Tabel 5. Laporan Realisasi Anggaran Lembaga Penyiaran Publik (LPP) RRI Stasiun Sumenep Periode 2008 dan 2009

\begin{tabular}{|c|c|c|c|c|}
\hline Nama Perkiraan & Anggaran 2008 & Realisasi & $\begin{array}{l}\text { Anggaran } \\
2009\end{array}$ & Realisasi \\
\hline \multicolumn{5}{|l|}{ ASET } \\
\hline \multicolumn{5}{|l|}{ Aset Lancar } \\
\hline Kas & Rp.42.000.000 & Rp.25.000.000 & Rp. 36.500 .000 & Rp.36.500.000 \\
\hline Persediaan & Rp.35.850.000 & Rp.27.500.000 & Rp. 45.000 .000 & Rp.42.120.000 \\
\hline Jumlah Aset Lancar & Rp.77.850.000 & Rp.52.500.000 & Rp.81. 500.000 & Rp.78.620.000 \\
\hline \multicolumn{5}{|l|}{ Aset Tetap } \\
\hline Tanah & Rp.285.500.000 & Rp.256.455.000 & Rp.256.455.000 & Rp. 256.455 .000 \\
\hline Peralatan & Rp. 25.250 .000 & Rp. 20.520 .500 & Rp. 22.585 .300 & Rp. 22.585 .300 \\
\hline Gedung dan Bangunan & Rp. 35.500 .000 & Rp. 35.325 .000 & Rp. 41.212.000 & Rp. 41.212 .000 \\
\hline Inventaris Kantor & Rp. 53.250 .000 & Rp. 40.000 .050 & Rp. 40.587 .000 & Rp. 43.452 .000 \\
\hline Penyusutan & Rp.(13.650.250) & Rp. (3.250.000) & Rp. (3.897.800) & Rp. (4.673.000) \\
\hline Aset Tetap Lainnya & Rp. 22.520 .000 & Rp. 35.650 .000 & Rp. 43.256 .000 & Rp. 38.900 .000 \\
\hline Jumlah Aset tetap & Rp.408.369.750 & Rp.384.690.550 & Rp.400.197.500 & Rp.397.931.300 \\
\hline JUMLAH ASET & Rp.486.219.750 & Rp.437.190.550 & Rp.481.697.500 & Rp.476.551.300 \\
\hline $\begin{array}{l}\text { KEWAJIBAN } \\
\text { Kewajiban Jangka Pendek }\end{array}$ & & & & \\
\hline Uang muka dari KPPN & Rp.250.000.000 & Rp. 250.000 .000 & Rp.205.550.000 & Rp.225.000.000 \\
\hline Jumlah Kewajiban J. Pendek & Rp.250.000.000 & Rp.250.000.000 & Rp.205.550.000 & Rp.225.000.000 \\
\hline Jumlah Kewajiban & Rp.250.000.000 & Rp.250.000.000 & Rp.205.550.000 & Rp.225.000.000 \\
\hline
\end{tabular}




\begin{tabular}{|c|c|c|c|c|}
\hline Nama Perkiraan & Anggaran 2008 & Realisasi & $\begin{array}{l}\text { Anggaran } \\
2009\end{array}$ & Realisasi \\
\hline \multicolumn{5}{|l|}{ EKUITAS DANA } \\
\hline \multicolumn{5}{|l|}{ EKUITAS DANA LANCAR } \\
\hline Cadangan Persediaan & Rp.183.000.150 & Rp.173.500.000 & Rp.214.550.000 & Rp.214.550.000 \\
\hline Jumlah Ekuitas Dana Lancar & Rp.183.500.150 & Rp.173.500.000 & Rp.214.550.000 & Rp.214.550.000 \\
\hline \multicolumn{5}{|l|}{ EKUITAS DANA INVESTASI } \\
\hline Diinvestasikan dalam aset tetap & Rp. 52.719 .600 & Rp. 13.690 .550 & Rp. 61.597 .500 & Rp. 37.001 .300 \\
\hline Jumlah Ekuitas Dana Investasi & Rp. 52.719.600 & Rp. 13.690 .550 & Rp. 61.597.500 & Rp. 37.001.300 \\
\hline Jumlah Ekuitas Dana & Rp.236.219.750 & Rp.187.190.550 & Rp.276.147.500 & Rp.251.551.300 \\
\hline $\begin{array}{l}\text { JUMLAH KEWAJIBAN DAN } \\
\text { EKUITAS DANA }\end{array}$ & Rp.486.219.750 & Rp.437.190.550 & Rp.481.697.500 & Rp.476.551.300 \\
\hline
\end{tabular}

Sumber :LPP RRI Stasiun Sumenep dan Data diolah oleh peneliti

Berdasarkan proyeksi neraca serta realisasi neraca pada periode 2008 dan 2009, Lembaga Penyiaran Publik (LPP) RRI Stasiun Sumenep di dalam laporan realisasi anggaran ternyata anggaran tidak sepenuhnya dapat terealisasi karena didalam penganggarannya LPP RRI Stasiun Sumenep tidak dapat merealisasikan anggaran yang telah di anggarkan sehingga dengan tidak sepenuhnya terealisasi maka pada tahun berikutnya yaitu 2009 anggarannyapun semakin berkurang. Hal tersebut disebabkan oleh rekening berkurangnya jumlah aset yang biasanya di tahun 2008 jumlah aset sebesar Rp. 486.219.750,00 dan terealisasi sebesar Rp. 437.190.550,00 sedangkan penurunan jumlah aset di tahun 2009 sebesar Rp. 481.697.500,00 dan terealisasi sebesar Rp. 476.551.300,00 namun demikian dengan berkurangnya jumlah aset tetapi realisasinya lebih tinggi di tahun 2009 dibandingkan dengan tahun 2008 . Karena di tahun 2009 aset semakin bertambah.

Berdasarkan data realisasi anggaran maka dapat disimpulkan bahwa anggaran pendapatan lebih tinggi dari yang telah terealisasi sehingga LPP RRI Stasiun Sumenep untuk memenuhi program kerjanya maka LPP RRI Stasiun Sumenep harus mencari terlebih dahulu anggaran yang dibutuhkan untuk memenuhi kebutuhan dan biaya-biaya yang diperlukan untuk produksi suatu biaya operasional.

Tabel 6. Laporan Realisasi Anggaran Pendapatan Periode 2008/2009

\begin{tabular}{|c|c|c|c|c|c|}
\hline No & Uraian & Anggaran 2008 & Realisasi & Anggaran 2009 & Realisasi \\
\hline 1 & $\begin{array}{l}\text { PENDAPATAN } \\
\text { 1. Iklan } \\
\text { 2. Sewa Gedung } \\
\text { 3. Silang } \\
\text { 4. Talkshow } \\
\text { 5. Kontrak Program } \\
\text { 6. Layanan Masy } \\
\text { 7. Sewa Sound } \\
\end{array}$ & $\begin{array}{lr}\text { Rp. } & 100.000 .000 \\
\text { Rp. } & 85.000 .000 \\
\text { Rp. } & 750.000 \\
\text { Rp. } & 9.230 .000 \\
\text { Rp. } 110.000 .000 \\
\text { Rp. } 52.210 .000 \\
\text { Rp. } & 50.000 .000\end{array}$ & $\begin{array}{lr}\text { Rp. } & 91.436 .600 \\
\text { Rp. } & 78.118 .850 \\
\text { Rp. } & 965.000 \\
\text { Rp. } & 1.151 .300 \\
\text { Rp. } & 101.021 .180 \\
\text { Rp. } & 62.845 .700 \\
\text { Rp. } & 62.672 .300\end{array}$ & $\begin{array}{lr}\text { Rp. } & 250.000 .000 \\
\text { Rp. } & 50.000 .000 \\
\text { Rp. } & 500.000 \\
\text { Rp. } & 1.000 .000 \\
\text { Rp. } & 35.000 .000 \\
\text { Rp. } & 40.000 .000 \\
\text { Rp. } & 20.000 .000\end{array}$ & $\begin{array}{lr}\text { Rp. } & 281.979 .150 \\
\text { Rp. } & 59.970 .400 \\
\text { Rp. } & 654.000 \\
\text { Rp. } & 1.478 .000 \\
\text { Rp. } & 44.473 .595 \\
\text { Rp. } & 49.321 .600 \\
\text { Rp. } & 24.917 .000\end{array}$ \\
\hline \multicolumn{2}{|c|}{ Jumlah Total } & Rp. 407.190.000 & Rp. 398.210.930 & Rp. 416.500.000 & Rp. 462.793 .745 \\
\hline 2 & $\begin{array}{l}\text { BELANJA } \\
\text { 1. Pegawai } \\
\text { 2. Operasional } \\
\text { 3. Pemeliharaan }\end{array}$ & $\begin{array}{l}\text { Rp. } 300.000 .000 \\
\text { Rp. } 35.000 .000\end{array}$ & $\begin{array}{l}\text { Rp.300.000.000 } \\
\text { Rp. } 29.448 .550\end{array}$ & $\begin{array}{lr}\text { Rp. } & 330.000 .000 \\
\text { Rp. } & 11.000 .000 \\
\text { Rp. } & 25.000 .000 \\
\end{array}$ & $\begin{array}{l}\text { Rp.330.000.000 } \\
\text { Rp. } 12.689 .565 \\
\text { Rp. } 29.692 .900 \\
\end{array}$ \\
\hline
\end{tabular}




\begin{tabular}{|c|c|c|c|}
\hline & Rp. 50.000 .000 & Rp. 43.958 .700 & \\
\hline Jumlah Total & Rp. 420.000.000 & Rp. 373.407.250 & Rp. 372.382.465 \\
\hline
\end{tabular}

\section{SIMPULAN}

Sistem komputerisasi pada LPP RRI Stasiun Sumenep maka perhitungan efektifitas pendapatan lebih efektif pada tahun 2009 dari pada tahun 2008. Berdasarkan proyeksi neraca serta realisasi neraca pada periode 2008 dan 2009, Lembaga Penyiaran Publik (LPP) RRI Stasiun Sumenep di dalam laporan realisasi anggaran ternyata anggaran tidak sepenuhnya dapat terealisasi.

Berdasarkan penggunaan SIMAK (Sistem Manajemen Aplikasi Komputer) maka tingkat kerja dari sebuah sistem produksi lebih semakin cepat dan mudah serta dapat mengefektifkan suatu pendapatan, dengan peningkatan $2,57 \%$ maka LPP RRI Stasiun Sumenep dapat mencapai efektifitas suatu pendapatan di LPP RRI Stasiun Sumenep. 


\section{DAFTAR PUSTAKA}

Baridwan, Zaki. 1997. Sistem Informasi Akuntansi, Edisi ke-3.

Baridwan, Zaki. 2004. Intermediate Accounting. BPFE. Yogyakarta.

Hall, James A. 2007. Sistem Informasi Akuntansi. Buku 1, Edisi ke-4, Salemba Empat. Jakarta.

Mowen, Hansen, 2005. Akuntansi Manajemen 2. Edisi ke-7. Erlangga. Jakarta.

Mulyadi. 2001. Sistem Akuntansi. Salemba Empat, Jakarta.

Munawir, S. 2004. Akuntan. Analisa Laporan Keuangan. Edisi ke-4. Penerbit : Liberty, Yogyakarta.

Supomo Bambang, Abdul Halim. 2007. Akuntansi Manajemen. BPFE. Yogyakarta.

Supranto, Johannes M.A. 1991. Teknik Pengambilan Keputusan. Rineka cipta. Jakarta.

Syafri H., Sofyan. 2006. Analisis Kritis Atas Laporan Keuangan. PT. Raja Grafindo Persada, Jakarta.

Widjajanto, Nugroho. 2001. Sistem Informasi Akuntansi. Erlangga. Jakarta. 